\section{Bahtinista on moneksi}

XII kansainvälinen Bahtin-kongressi Jyväskylässä kesällä 2005.

Kahdestoista kansainvälinen Bahtinkongressi järjestettiin viime heinäkuussa 18. - 22. päivänä Jyväskylässä. Osanottajia oli ympäri maailmaa, kaikki Bahtinista, Bahtinin käsitteiden soveltamisesta ja Bahtinin piirin ajattelusta kiinnostuneita eri alojen tutkijoita. Esitelmien ja työryhmäpapereiden aiheet olivatkin varsin monipuolisia. Puhuttiin Bahtinin piirin teosten synnystä ja historiasta, Bahtinin ajattelun konteksteista niin Bahtinin elinaikana kuin tämän hetken tutkimuksessakin, Bahtinin vaikutuksesta estetiikkaan, filosofiaan, kirjallisuudentutkimukseen sekä humanistisiin ja yhteiskuntatieteisiin yleisemmin.

Suomalaisittain mielenkiintoinen oli neljän eri puolilta maailmaa lähtöisin olevan kirjallisuudentutkijan Bahtinin käsitteisiin perustuva tulkinta Bo Carpelanin teoksesta Urwind. He olivat tulkinneet Carpelanin teosta toisistaan - ja ajoittain tuntui, että myös suomalaisesta kontekstista - tietämättä. Välillä vaikutti siltä, että tulkitsijat puhuivat neljästä eri teoksesta. Se ei kuitenkaan ollut negatiivista. Päinvastoin. Se osoitti, kuinka moneen suuntaan nekin tulkinnat, jotka pitäytyvät yhteen teoreetikkoon, voivat liikkua.
Urwindin tulkintojen paneelissa tuli esille joitakin niistä ongelmista, joita tämänhetkiseen Bahtiniin pohjautuvaan tutkimukseen liittyy kirjallisuudentutkimuksen alalla. Paneelin amerikkalainen puheenjohtaja Brian Kennedy totesi, että tämän päivän kirjallisuudentutkimuksessa Bahtin näyttää paradoksisesti olevan läsnä kaikkialla eikä oikeastaan missään. Tällä hän viittasi siihen, että erityisesti sellaiset Bahtinin käsitteet kuin karnevaali ja dialogismi kuljeskelevat tutkimuksissa ikään kuin kaikki tietäisivät, mitä ne tarkoittavat. Tässä mielessä Bahtin on kaikkialla. Kuitenkin sellaisen tutkimuksen osuus, jossa olisi todella paneuduttu Bahtinin (piirin) kirjoituksiin, on vähentynyt radikaalisti kirjallisuudentutkimuksessa sitten Bahtin-boomin päivien.

Kirjallisuudentutkijan kannalta kongressi oli antoisa siinä mielessä, että useat kansainvälisesti tunnetut Bahtintutkijat toivat esitelmissään esiin Bahtintutkimuksen nykytilanteen. Kongressissa esiintyivät monet suomalaisillekin ainakin niminä tutut Bahtin-tutkijat, kuten Caryl Emerson, Ken Hirschkop, Peter Hitchcock, Galin Tihanov, Sergei Bocharov ja David Shepherd. Suomen Akatemian rahoittama tutkimusryhmämme “Tekijän paluu” oli lukenut tiiviisti koko viime kevään Bahtinin kirjoituksia nimenomaan tekijyys-käsitysten valossa, ja meille tarjoutuikin kongressin aikana tilaisuus keskustella Sheffieldin yliopiston professorin David Shepherdin kanssa Bahtin-tutkimuksen nykytilanteesta.

Sheffieldin yliopistossa toimii Bahtin- 
keskus, joka on perustettu vuonna 1994. Keskusta johtaa yhä sen perustaja, professori David Shepherd. Hän lienee suomalaisille kirjallisuudentutkijoille tuttu ainakin Bahtinia käsittelevästä teoksesta, Bakhtin and Cultural Theory, jonka hän toimitti yhdessä Ken Hirschkopin kanssa vuonna 1989. Siitä ilmestyi laajennettu laitos vuonna 2001.

Shepherdin johtaman keskuksen tarkoituksena on edistää monitieteistä ja tieteidenvälistä Bahtin-tutkimusta sekä sitä sivuavaa kulttuurin, kirjallisuuden ja kielen tutkimusta. Pääpaino keskuksen työssä on ollut Bahtinin ajatusten tarkasteleminen syntykontekstissaan. Tämä näkyy myös hänen toimittamassaan teoksessa The Contexts of Bakhtin: Philosophy, Authorship, Aesthetics, joka ilmestyi vuonna 1998. Tuorein Bahtin ajattelua kontekstualisoivia artikkelikokoelma on The Bakhtin Circle: In the Master's Absense (toim. David Shepherd, Craig Brandist \& Galin Tihanov, 2004). Bahtin-keskus julkaisee myös tieteellistä aikakauslehteä Dialogism: An International Journal of Bakhtin Studies.

Kongressin lounastauolla paahtavassa auringonpaisteessa käyty keskustelu David Shepherdin kanssa kulki seuraavaan tapaan:

Kysymys: Kertoisitko meille Bahtin-keskuksen toiminnasta.

Vastaus: Keskuksen päämäärä on edistää Bahtinin ja Bahtinin piirin tutkimusta sekä yleistä kulttuurintutkimusta ja sen teoriaa. Ensisijaisesti keskitymme Bahtiniin, mutta muutakin tutkimusta keskuksessa tehdään. Keskus ei ole yliopistollinen laitos perinteisessä mielessä, mutta se toimii yhteydessä yliopiston eri laitoksiin. Meillä on meneillään satakunta tutkimushanketta, ja itse sain rahoituksen vuonna 1997 tutkimukseen nimeltä "Bahtinin ja Bahtinin piirin venäläiset ja eurooppalaiset kontekstit." Tutkimus jatkuu vieläkin, ja se vaikuttaa loputtomalta. Hanke on tuottanut useita kirjoja ja artikkeleita. Keskus tuottaa myös kriittisen edition Bahtinin kirjoituksista sekä venäjäksi että englanniksi. Tämä on meidän tämänhetkinen "suuri projektimme". Toivomme pian saavamme julkaistuksi käännöksen kaikista niistä teksteistä, jotka on koottu Bahtinin venäjänkieliseen koottujen teosten viidenteen osaan. Siihen sisältyvät Bahtinin kirjoitukset vuodesta 1942 aina 1960-luvun teksteihin. Tämä on tärkeä käännösprojekti, sillä monillakaan ei ole ollut mahdollisuutta tutustua näihin teksteihin aiemmin.

Toinen suuri hanke on rakentaa tietopankki Bahtinin ja Bahtinin piirin teoksista; nehän eivät kaikki ole vielä saatavilla. Tarkoituksena on myös tuottaa näistä aineistoista elektroninen versio, mutta meillä on sen suhteen ollut vaikeuksia sopimusten saamisessa. Meillä on myös paljon tutkijaopiskelijoita. Useimpien väitöskirjat ovat Bahtinista, mutta eivät kaikkien. Kirjallisuuden- ja kulttuuritutkimuksen nykyisen kentän laaja-alaisuus on heijastunut myös Bahtin-keskukseen, ja toivon tämän suuntauksen jatkuvan. Bahtin-tutkimuksen pitää laajentua ja ottaa huomioon muiden oppialojen suun- 
taviivat.

K: Näyttää siltä, että tutkijoiden kesken vallitsee melkoinen erimielisyys siitä, onko Bahtinia syytä "soveltaa”. Täällä Jyväskylässä nähtiin mielenkiintoinen esimerkki Bahtinin soveltamisesta, kun neljä tutkijaa tulkitsi Bo Carpelanin romaania. Tosin tämänkin osuuden lopuksi puheenjohtajana toiminut Peter Hitchcock korosti soveltamisen ongelmallisuutta. Hitchcockin mukaan on tärkeämpää miettiä Bahtinin sovellettavuuden rajoja kuin tuottaa uusia luentoja, joissa Bahtinin käsitteitä käytetään kyseenalaistamatta. Mitä mieltä olet tästä?

V: Olen ollut hyvin tiukasti sitä mieltä, että Bahtinin käsitteitä ei pitäisi "soveltaa” ennen kuin hänen ajatuksensa on saatu kokonaan selvitetyksi. Mutta toisaalta, miksi näiden yhteyksien selvittäminen sitten olisi merkityksellistä? Jotta saataisiin Bahtin siististi laatikkoon? Nyt olen jo valmis myöntämään, että sovellutuksilla on arvonsa Bahtinin käsitteiden testaamisessa. Mutta kyllä eksegetiikkakin on tärkeää, jotta käsitteet täsmentyisivät.

K: Tämänkesäisen kongressin perusteella meistä on näyttänyt myös siltä, että venäläiset tutkijat ovat asenteeltaan huomattavasti kriittisempiä Bahtinin soveltamista kohtaan kuin läntiset tutkijat. Näetkö tällaista rajanvetoa, ja onko venäläisten Bahtin jotenkin erilainen kuin läntisten tutkijoiden?

$\mathrm{V}$ : Manchesterin kongressi vuonna 1991, jota olin itse järjestämässä, oli ensimmäinen, jossa myös venäläiset tutkijat olivat mukana. Kielivaikeuksien vuoksi kongressissa oli jonkin verran hankaluuksia, mutta myös siksi, että venäläisten tutkijoiden intressit erosivat paljon länsimaalaisten intresseistä. Kamalaa rakentaa tällaista binaarisuutta "länsi” -"Venäjä”! Jonkinlainen rajalinja on edelleen olemassa, mutta kyllä linja kulkee nyt myös yli kielirajojen. Ehkä ero kulkee nykyisin aatehistorioitsijoiden ja soveltajien välillä. Vaikuttaa kuitenkin siltä, että useimmat venäläiset kuuluvat aatehistorialliseen linjaan, kun taas "länsi” on jakautunut aatehistoriaan ja soveltajiin. On totta, että Bahtin-tutkimus on aina ollut hieman lokeroitunutta.

Se, että läntiset tutkijat ovat innokkaampia soveltamaan Bahtinia, liittyy varmasti myös siihen, miten Bahtin tuli läntisten tutkijoiden tietoisuuteen ja siihen, miten Bahtin omaksuttiin. Rablaiskirja ilmestyi ranskaksi 1960-luvulla, englanniksi 1968, The Dialogic Imagination vuonna 1981. Näistä alkoi buumi, joka liittyi kirjallisuuden- ja kulttuurintutkimuksen kovan teorian (high theory) vaiheeseen. Tämä vaihe sai Bahtinin näyttämään joltakin, joka voisi sekoittaa korttipakkaa ja tarjota jonkinlaisen välittäjän aseman. Käännökset edesauttoivat tuota vaikutelmaa. Jos ajattelemme esimerkiksi The Dialogic Imagination -teoksen nimeä, siinä ei ole mitään järkeä venäjäksi. Se on amerikkalainen otsikko amerikkalaiselle lukijakunnalle.

K: Toisaalta on näkyvissä, että loputtoman soveltamisen seurauksena jotkin Bahtinin käsitteet (esimerkiksi dialogi- 
suus, karnevalismi) ovat muuttuneet tiettyjen ilmiöiden yleisnimiksi eikä niillä ole enää paljoakaan tekemistä Bahtinin kanssa. Onko tämä mielestäsi ongelma?

V: Bahtin-tutkimuksen näkökulmasta se voi olla ongelma, ei ehkä niinkään kirjallisuudentutkimuksen näkökulmasta. Kirjallisuudentutkijat uskovat, että käyttämällä Bahtinin nimeä ja käsitteitä he saavat laatutodistuksen tutkimukselleen. Bahtin-tutkimukselle käsitteiden irrottaminen konteksteistaan on kuitenkin todellinen ongelma. Käsitteistä tulee vapaasti kelluvia esineitä, kun ne irrotetaan kiinnikkeistään. Ja ongelmaa lisää se, että olemme vasta nyt oppimassa, mitä nämä kiinnikkeet ylipäänsä ovat. Ne vaikuttavat paljon monimutkaisemmilta kuin aikaisemmin on ajateltu. Voidaan kysyä, onko sillä tavalla, jolla Bahtin päätyi karnevaali-käsitteeseensä oikeastaan mitään tekemistä monien nykytutkimusten karnevaali-käsitteen käyttämisen kanssa. Karnevaalia on kuitenkin sovellettu siihen pisteeseen saakka, että siitä on tullut itsensä parodiaa!

Minua haastateltiin eräässä televisioohjelmassa aikaisemmin tänä vuonna. Ohjelmassa keskusteltiin muun muassa Länsi-Intian karnevaaleista, joihin Bahtinilla on hyvin vähän sanottavaa. Ohjelmassa keskusteltiin myös brittiläisten nuorten nykyisestä "illanviettotavasta": nuoret maleksivat iltaisin kadulla, kuten nuoret tekevät itseään huvittaakseen, mutta heillä on myös tapana sytyttää esineitä palamaan. Eräs sosiologi yritti tulkita tätä karnevaalin hengen ilmauksena, koska Bahtin kirjoittaa karnevaalin yhteydessä myös tulipaloista ja nuotioista. Minulta kysyttiin, mitä ajattelen tästä. Vastasin ajattelevani paljonkin. Mielestäni kyse on varsinaisen kysymyksen välttelemisestä. Oikea kysymys on: miksi lapset reagoivat näin? Miksi he aiheuttavat vaaraa sekä itselleen että muille ja turmelevat omaisuutta? Jos vastataan, että lapset ilmaisevat karnevalistista henkeä, on kyse Bahtinin käsitteen väärinkäytöstä ja oman tulkinnan myyvyydestä. Tämä keskustelu on kuvaava esimerkki siitä, kuinka Bahtinin käsite on revitty todella kauas alkuperäisistä yhteyksistään. Sillä ei ole enää mitään tekemistä Bahtinin kanssa.

K: Toimittamassasi teoksessa The Contexts of Bakhtin kirjoitat ironisesti siitä, kuinka ne tutkijat, jotka äänekkäimmin korostavat kontekstin merkitystä Bahtinia käyttäessään, irrottavat hänet kaikista konteksteista. Oletko sitä mieltä, että Bahtinia voi ymmärtää vain, jos tuntee hänen ajattelunsa "alkuperäiset" kontekstit?

V: Olen lujasti sitä mieltä, että meidän täytyy jatkaa Bahtinin kontekstualisointia. Paljon on tehty, mutta vielä enemmän pitää tehdä. Toisaalta on aika lopettaa ajattelu, että Bahtinia ei voisi soveltaa muille aloille. Häntä pitää soveltaa, muuten hänestä tulee museoesine. Meidän täytyy myös kamppailla sellaisten venäläisten tutkijoiden kanssa, jotka sanovat, että et voi ymmärtää Bahtinia, koska et ole venäläinen. Näissä kongresseissa on aina mukana ihmisiä, joille Bahtin on upouusi tuttavuus. Meidän, jotka 
olemme roikkuneet mukana pitkään, pitäisi rohkaista uusia tulokkaita löytämään oma Bahtininsa. Ja usein tämä merkitsee "de-kontekstualisointia."

K: Mitä mieltä olet tutkimuksesta, jonka juuret ovat alkujaan Bahtinissa, mutta joka kulkee toiseen suuntaan? Ajattelemme nyt esimerkiksi Bahtiniin pohjautuvaa feminististä tutkimusta. Voisiko ajatella, että Bahtinin käsitteet voisivat synnyttää kokonaan uudenlaisia kysymyksenasetteluja? Tällaisessa tapauksessahan ei oikeastaan ole kysymys soveltamisesta.

V: Niin, Bahtinin käsitteet ovat silloin ikään kuin stimulantteja, jotka ohjaavat toisiin kysymyksiin. Bahtin toimii katalysaattorina ja metodologisen inspiraation antajana. Hän tekee mahdolliseksi jotakin, mikä muuten ei kenties olisi ollut mahdollista. Mitä feminismiin tulee, muistan venäläisten ja muiden väliset kiistat 1990-luvulta tässä asiassa. Vuoden 1991 kongressin papereissa oli viittauksia "noihin hirveisiin feministeihin", jotka käyttivät Bahtinia “väärin”, koska Bahtin ei koskaan puhunut mitään feminismistä. Tämä liittyy Bahtinin kontekstualisoinnin korostamisen vaarapuoliin. Jos kiinnostuu asioista, joita Bahtin ei maininnut tai sanoista, joita hän ei käyttänyt, on vaarana, että saa helposti erittäin kriittistä palautetta: Bahtin ei sanonut noin tai ei tarkoittanut tuota. Tämä on nähdäkseni väärää logiikkaa.

K: Meissä on herättänyt hämmennystä Bahtinin tapa käyttää käsitteitä. Hän saattaa antaa niille ristiriitaisia määritelmiä tai käyttää niitä epämääräisesti. Tä- mäkin lienee omiaan synnyttämään kiistoja hänen käsitteistään. Miten suhtaudut tähän?

V: Vaikea kysymys. Tässä yhteydessä pitäisi ottaa kontekstualisointi huomioon. On ongelmallista sulauttaa kaikki Bahtinin tekstit yhteen vaikkapa "Kirjailija ja sankari"-tekstin perusteella tai Dialogic Imagination -teoksen esseiden perusteella, vaikka ne juontuisivatkin samalta teoreettiselta pohjalta. Minä muutan näkemyksiäni hyvinkin lyhyen ajan sisällä. Tekstien sekoittaminen tyyliin 'hitunen puhelajeista, hitunen Dialogic Imaginationista' on erittäin ongelmallista kontekstuaalisuuden vuoksi. Moni venäläinen tutkimus $\mathrm{Neu}-$ vostoajoilta teki tällaista yhdistelyä.

Miten Bahtin itse toimi, siitä on vaikea sanoa mitään. Täytyy muistaa, että moni hänen teksteistään jäi julkaisematta, esimerkiksi fenomenologiset tekstit. Joidenkin tekstien kielenkäyttöä muutettiin sopimaan muihin teksteihin, niitä 'sosiologisoitiin'. Vaikka Bahtin ei saanut kaikkia tekstejään julkaistua, hän ei kuitenkaan ollut mikään vastustava, dissidentti-tyyppinen tutkija, joka ei haluakaan tulla julkaistuksi. Bahtin ei kirjoittanut pöytälaatikkoaan varten, hän halusi julkaista. Hänen uraansa voi tarkastella tämän projektiona: hän päätti kirjoittaa tästäjatästä asiasta, jotta tulisi julkaistuksi, ja jotta hän voisi saada hyvän akateemisen viran. Esimerkiksi romaania koskevat esseet ovat suurelta osin hänen vastauksensa siihen keskusteluun, jota käytiin romaanista Neuvostoliitossa 1940-luvulla, eivätkä niinkään hänen yksinäisen, post- 
kantilaisen ponnistelunsa tuloksia. Olen kutsunut tätä hänen "julkaisusäännökseen”, "osallistumissäännökseen”. Se sai hänet kiinnittämään huomiota tiettyyn problematiikkaan. Hän ei siis ollut niin kaukana tuon ajan "virallisista" ajattelijoista kuin voisi ajatella. Tämä tarkoittaa, että teksteissä on tietysti aina mukana oma sisäinen logiikkansa. Mutta niissä on myös tärkeitä ulkopuolisia herätteitä, jotka saivat Bahtinin keskittymään tiettyihin asioihin tiettyinä aikoina. Hänen tekstinsä eivät siis rakennu pelkästään sisäisen logiikan mukaan.

K: Mielestäsi on siis aivan paikallaan puhua varhaisesta Bahtinista ja myöhäisestä Bahtinista?

V: Ehdottomasti, se on jopa välttämätöntä. Totta kai hänen myöhemmissä kirjoituksissaan on merkkejä varhaisista töistä, mutta myös erot voivat olla suuria.

K: Olet kirjoittanut, että Bahtin ei oikeastaan missään tarjoa teoriaa lukijasta, mikä on erikoista, koska hän kuitenkin puhuu alituiseen kuulijasta/kuuntelijasta ja lukijasta. Eikö sama päde myös tekijään? Bahtin puhuu lukuisissa yhteyksissä tekijästä, mutta mitään tekijyyden teoriaa hänen teksteistään on vaikea löytää.

$\mathrm{V}$ : Niiden kirjoitusten juuret, joissa Bahtin puhuu tekijästä, ovat erilaisia. Esimerkiksi "Kirjailija ja sankari” -tekstin tekijänäkemystä kannattaisi pohtia siltä osin, mikä siinä voisi olla käytettävissä ja kehiteltävissä eteenpäin. Mutta sitä tulisi suhteuttaa myös myöhempiin näkemyksiin, joissa hän on eri mieltä. Tämä johtaa siihen, että olisi pohdittava mitä Bahtin itse tekee omille näkemyksilleen. Ja sitten toisaalta on vaarallista ajatella, että hänellä olisi jonkinlainen tekijyyden malli teksteissään. Hänellä ei ole paljoakaan sanottavaa taloudellisten asioiden vaikutuksesta tekijyyteen tai painotekniikkakulttuurin yhteyksistä tekijyysnäkemyksiin. Hän kirjoittaa pitkästi romaanin historiasta, mutta missä on institutionaalinen näkemys? Missä kirjallisuuden nousu maallisena instituutiona? Bahtin ei käsittele tällaisia kysymyksiä, mutta mielestäni niitä pitää pohtia tekijän yhteydessä.

K: Teoksessasi Beyond Metafiction - Self-Consciousness in Soviet Literature (1992) toteat, että Roland Barthesin "tekijän kuolema” -metafora ei yksinkertaisesti sovellu neuvostokirjallisuuden kontekstiin. Miksi ei?

V: Neuvostoliiton historia on esteenä sille, että tekijä-kysymystä voitaisiin arvioida uudelleen Barthesin termein. Moni kirjailija kuoli, tapettiin, ammuttiin väärin kirjoittamisesta. Venäläisessä kulttuurissa on kirjoitetun sanan tärkeyden henki, tekijän tärkeys. Tässä suhteessa teoreettinen puhe tekijän kuolemasta ei oikein sovi, se olisi kulttuurisesti epäkorrektia. Ei voi sanoa, että kiinnitetäänpä nyt huomio lukijaan eikä välitetä kirjailijan intentioista. Teoksella voi olla vaikutuksia, jotka ylittävät tekijän intentiot ja ovat niiden kanssa ristiriitaisia. Meidän täytyy silti ymmärtää ajatus tekijästä alkuperäisenä hahmona, jolla on oikeus tulla ymmärretyksi intentionaalisena hahmona. Ei voi puhua tekijän kuolemasta Ve- 
näjällä samassa suhteessa kuin lännessä. Se ei olisi eettistä. Kyse on etiikasta eikä etiketistä, joka on etiikan trivialisointia. Täytyy olla hienovarainen. Tekijän kuoleman juhliminen olisi absurdia tässä yhteydessä.

Keskustelemassa David Shepherdin lisäksi:

Viola Parente-Čapková

Elsi Hyttinen

Kaisa Kurikka

Milla Peltonen

Veli-Matti Pynttäri

Lea Rojola

\section{Onko pervouttamisella mitään rajaa?}

Pervot puheet: teorian ja aktivismin risteymiä. Turun 5. valtakunnallinen lesbo-, homo- ja queer-tutkimusseminaari. Åbo Akademi 21.-23.10.2005

Kirjallisuuden- ja taiteentutkijoita aina kiinnostava Turun valtakunnallinen lesbo-, homo- ja queer-tutkimusseminaari järjestettiin tänä vuonna Åbo Akademissa. Teemana oli teorian ja aktivismin kohtaaminen. Seminaari, joka koostui niin ulkomaisista kuin kotimaisista luennoitsijavieraista, työryhmistä ja paneelikeskustelusta, osui ajan hermoon. Onhan koko syksyn Suomessa jännitetty ja kauhisteltu Ruotsissa alkanutta poliittista, median inspiroimaa, konservatiivista takaiskua. Feministisen puolueen (FI) ympärille kietoutuneen näytelmän näkyvimmäksi kohteeksi on joutunut Pohjolan tunnetuin queer-teoreetikko ja aktivisti, suomalaissyntyinen teatterintutkija ja Tukholman yliopiston professori Tiina Rosenberg. Ruotsin tilanne puhutti luonnollisesti seminaariväkeä; suomalaisen ja ruotsalaisen julkisuuden ja julkisen keskustelun eroja pohdiskeltiin useaan otteeseen.

Kirjallisuudentutkijalle Pervot puheet avasi erityisesti uusia näkökulmia tekstuaalisuuden ja queeriyden suhteen. Pervous ei ilmene pelkästään kirjallisesti, vaan tekstuaaliseksi queeriksi näyttää 